\title{
Anatomy and cell wall ultrastructure of sunflower stalk rind
}

\author{
Lizhen Wang ${ }^{1,2}$, Hao Ren ${ }^{1}$, Shengcheng Zhai ${ }^{1}$ and Huamin Zhai ${ }^{\text {* }}$
}

\begin{abstract}
The anatomy and ultrastructure of sunflower stalk rind are closely related to its conversion and utilization. We studied systematically the anatomy and ultrastructure of the stalk rind using light, scanning electron, transmission electron and fluorescence microscopy. The results showed that the stalk rind consisted of phloem fibers (PF), xylem fibers (XF), vessel elements (V), ground parenchyma cells (GPC), axial parenchyma cells (APC), xylem ray parenchyma cells (XRPC), and pith ray parenchyma cells (PRPC). These cell walls were divided into the middle lamella, primary wall, and secondary wall (S). It was found that the $S$ of $P F, X F$ and $V$ was further divided into three layers $\left(S_{1}-S_{3}\right)$, while the $S$ of $A P C, G P C$, XRPC and PRPC showed a non-layered cell wall organization or differentiated two $\left(S_{1}, S_{2}\right)$ to seven layers $\left(S_{1}-S_{7}\right)$. Our research revealed the plasmodesmata characteristics in the pit membranes (PMs) between parenchyma cells (interGPCs, inter-XRPCs, and inter-PRPCs). The morphology of the plasmodesmata varied with the types of parenchyma cells. The thickness and diameter of PMs between the cells (inter-Vs, V-XF, V-APC, and V-XRPC) were greater than that of PMs between parenchyma cells. The cell corners among parenchyma cells were intercellular space. The lignification degree of vessels was higher than that of parenchyma cells and fibers. The results will provide useful insights into the biological structure, conversion and utilization of sunflower stalk rind.
\end{abstract}

Keywords: Anatomy, Cell wall layer, Lignin distribution, Pit membrane, Sunflower stalk rind, Ultrastructure

\section{Introduction}

The ultrastructure of plant cell walls is important not only for plant biology, but also for the conversion and utilization of mature plants [1]. Considerable progress has been made in understanding the basic structure and function of wood cell walls, but the variation in cell wall structures in grasses remains poorly understood because of the high complexity and dynamic characteristics of the cell wall $[2,3]$. One of the key steps in lignocellulosic conversion is cell wall deconstruction. The anatomy and cell wall ultrastructure of lignocellulosic materials are closely related to their conversion and utilization [4].

Plant cell walls are typically described as complex multi-layered structures consisting of an ordered array of

\footnotetext{
*Correspondence: hzhai@njfu.edu.cn

1 Jiangsu Co-Innovation Center for Efficient Processing and Utilization of Forest Resources, Jiangsu Provincial Key Lab of Pulp and Paper Science and Technology, Nanjing Forestry University, Nanjing 210037, China Full list of author information is available at the end of the article
}

cellulose microfibrils embedded in a matrix of non-cellulosic polysaccharides and lignin [5]. The ultrastructure of plant cell walls includes a complex hierarchical structure and heterogeneous distribution of chemical components between different layers [6]. Plant cell walls are usually divided into the middle lamella $(\mathrm{ML})$, primary wall $(\mathrm{P})$, and secondary wall (S). The $\mathrm{S}$ is the thickest and accounts for the largest proportion of the cell wall volume [7]. Lignin is the primary component of plant cell wall. Generally, the concentration of lignin in cell corners (CCs) or compound middle lamella (CML) is higher than that in the S. It is worth noting that, as an important morphological region of the cell wall, there are few reports on the cell pits and intercell pit membranes (PMs). In the lignocellulosic biorefining process, the characteristics of cell wall layers and PMs affect the transverse transport of the solution, and then affect the efficiency of biomass conversion $[8,9]$.
SpringerOpen
C The Author(s) 2021. Open Access This article is licensed under a Creative Commons Attribution 4.0 International License, which permits use, sharing, adaptation, distribution and reproduction in any medium or format, as long as you give appropriate credit to the original author(s) and the source, provide a link to the Creative Commons licence, and indicate if changes were made. The images or other third party material in this article are included in the article's Creative Commons licence, unless indicated otherwise in a credit line to the material. If material is not included in the article's Creative Commons licence and your intended use is not permitted by statutory regulation or exceeds the permitted use, you will need to obtain permission directly from the copyright holder. To view a copy of this licence, visit http://creativecommons.org/licenses/by/4.0/. 
Sunflower (Helianthus annuus L.) is one of the main oil crops. With the increasing demand for vegetable oil, the planting area of sunflowers is increasing year by year. The global sunflower planting area exceeded 26.5 million hectares in 2017, and approximately 80-186 million tons of residual stalk was generated [10]. The stalk consists of the rind and pith, in which the weight percentage of rind is approximately $90 \%$ [11]. The stalk rind can be used for papermaking [12], producing composite materials [13], chemicals [14], and energy fuels [15]. Sun et al. studied the cell composition and arrangement of the base, middle, and top of sunflower stalks, and analyzed the effects of each portion microstructure on mechanical properties and water diffusion [16]. Mehdikhani et al. studied the length and width of stalk rind fiber, and discussed its performance in papermaking [10]. Currently, the anatomy of sunflower stalk rind is not detailed, and the ultrastructure of its fibers, vessel elements $(\mathrm{V})$, and parenchyma cells has not been reported. Hence, we analyzed the anatomy of stalk rind using light microscopy (LM), the cell pits characteristics using scanning electron microscopy (SEM), the ultrastructure of cell wall layers and PMs using transmission electron microscopy (TEM), and lignin distribution using fluorescence microscopy (FM) and scanning electron microscopy with energy dispersive X-ray analysis (SEM-EDXA), and measured cell wall layer thickness, the PMs thickness and diameter using a combination of TEM images and ImageJ software. This study aimed to reveal the anatomy and cell wall ultrastructure of sunflower stalk rind and to provide the basis for its conversion and utilization.

\section{Materials and methods Materials}

Sunflower stalk was collected from Wuchuan County, Inner Mongolia, China. After sunflower maturation, stalks with a height of approximately $2 \mathrm{~m}$ and diameter of approximately $20 \mathrm{~mm}$ were selected. The middle section of the stalk was taken, and the pith was removed manually. The stalk rind was air-dried and stored for further use.

\section{LM}

The stalk rind was cut into strips $(0.5-1 \mathrm{~cm}$ height) and embedded with polyethylene glycol 2000 [17]. Transverse and radial sections (30 $\mu \mathrm{m}$ thickness) were prepared using a sliding microtome (TU-213, Yamato Kohki Industrial, Saitama, Japan), then stained with Safranin O and mounted in glycerol. Anatomy of the stalk rind was observed using a light microscope (BH2, OLYMPUS, Japan).

\section{SEM}

The radial sections ( $30 \mu \mathrm{m}$ thickness) of the stalk rind were selected. Before imaging, the sections were sputter-coated with $8 \mathrm{~nm}$ of gold using an E-1010 sputter coater (Hitachi, Hitachinaka, Japan) for 120 s. The cell pit characteristics were observed using an environmental scanning electron microscope (Quanta 200, FEI Co., OR, USA) at an acceleration voltage of $20 \mathrm{kV}$.

\section{TEM}

The stalk rind was cut into sticks $\left(1 \times 1 \times 1 \mathrm{~mm}^{3}\right)$. The samples were embedded in Spurr's epoxy resin [18]. Transverse ultra-thin sections $(90 \mathrm{~nm})$ were cut with a diamond knife using an ultramicrotome (EM-UC6, Leica, Wetzlar, Germany). The sections were stained with $1 \% \mathrm{w} / \mathrm{v} \mathrm{KMnO}_{4}$ (prepared in $0.1 \% \mathrm{w} / \mathrm{v}$ sodium citrate) for $2 \mathrm{~min}$ at $25^{\circ} \mathrm{C}$. The cell wall layering structure and PMs characteristics were observed under a transmission electron microscope (JEM-1400, JEOL, Tokyo, Japan) at an accelerating voltage of $80 \mathrm{kV}$.

\section{FM}

Transverse sections (15 $\mu \mathrm{m}$ thickness) were dehydrated in a graded series of ethanol solutions, and then were mounted in $70 \%$ glycerol and covered with a coverslip. Sections were observed with a fluorescence microscope (BX51, Olympus, Tokyo, Japan) using mercury lamp for illumination and using light at 330-385 $\mathrm{nm}$ for imaging lignin autofluorescence.

\section{SEM-EDXA}

Transverse sections (15 $\mu \mathrm{m}$ thickness) were extracted with a benzene-ethanol mixture $(2: 1, \mathrm{v} / \mathrm{v})$ for $24 \mathrm{~h}$. The sections were then reacted with $1 \% \mathrm{w} / \mathrm{v} \mathrm{KMnO}_{4}$ for $5 \mathrm{~min}$ at $25^{\circ} \mathrm{C}$. A gold film (8 $\mathrm{nm}$ thickness) was coated on the sections with an E-1010 sputter coater (Hitachi). Finally, the distribution of lignin in the cell walls was analyzed by measuring the $\mathrm{Mn}-\mathrm{K} \alpha \mathrm{X}$-ray counts using a Quanta 200 environmental scanning electron microscope (FEI Co.) equipped with an energy dispersive $\mathrm{X}$-ray analyzer (Inca X-act, Oxford, England). The accelerating voltage and probe current used were $20 \mathrm{kV}$ and $80 \mu \mathrm{A}$, respectively. The point measurement of $\mathrm{Mn}-\mathrm{K} \alpha \mathrm{X}$-rays was performed using at least 10 cells per region.

\section{Ultrastructure measurements}

ImageJ software (available at http://rsb.info.nih.gov/ ij) was used to measure the cell wall layer thickness, PMs diameter $\left(D_{\mathrm{PM}}\right)$, and PM thickness $\left(T_{\mathrm{PM}}\right)$ based on TEM images. The cell wall layer thickness was measured for at least 20 cells per cell type. The $D_{\mathrm{PM}}$ and $T_{\mathrm{PM}}$ 
measurements were recorded for more than 20 PMs per pit-pair type.

\section{Results and discussion Anatomy features}

The LM images showed the transverse and radial anatomy of sunflower stalk rind (Fig. 1). The stalk rind consisted of the epidermis (Ep), vascular bundles, and parenchyma tissues. The Ep was composed of epidermal membrane and epidermal cells, was located in the outermost layer of the stalk rind. The vascular bundle tissues were arranged in a ring and consisted of phloem
$(\mathrm{Ph})$, vascular cambium (VC), and xylem (X). Ph consisted of phloem fibers (PF). X consisted of xylem fibers (XF), vessel elements (V), axial parenchyma cells (APC), and xylem ray parenchyma cells (XRPC). The cell composition and arrangement of $\mathrm{X}$ were similar to that of porous wood [19]. There were several types of parenchyma cells in the stalk rind, including ground parenchyma cells (GPC), APC, XRPC, and pith ray parenchyma cells (PRPC). The GPCs were distributed near the Ep, while the APCs and XRPCs were scattered around the $\mathrm{V}$ and XF. The number of PRPC differentiated cells was large, usually present in multiple rows.

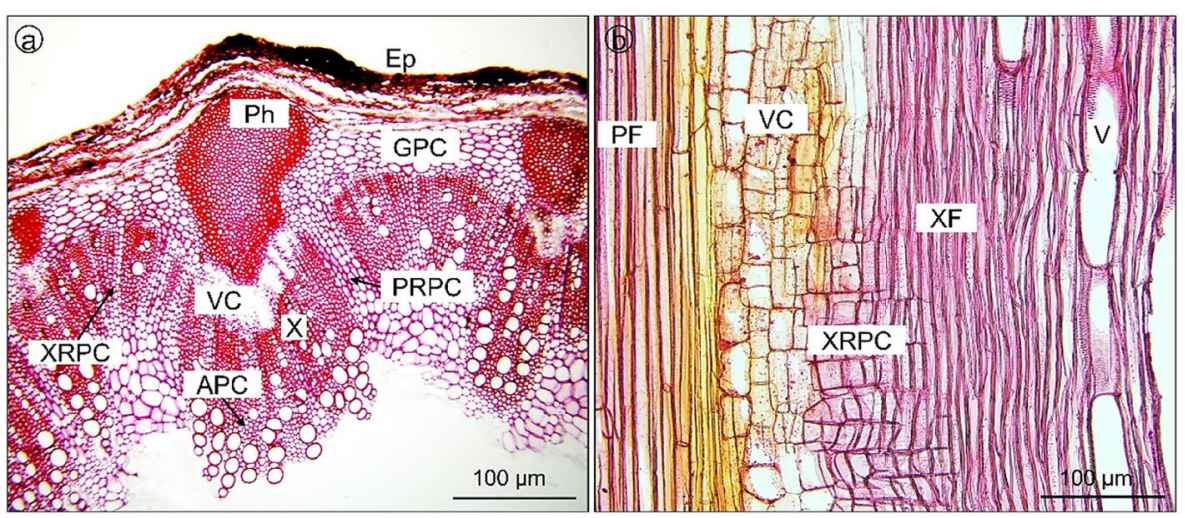

Fig. 1 LM images of the anatomy of sunflower stalk rind: $\mathbf{a}$ transverse section; $\mathbf{b}$ radial section
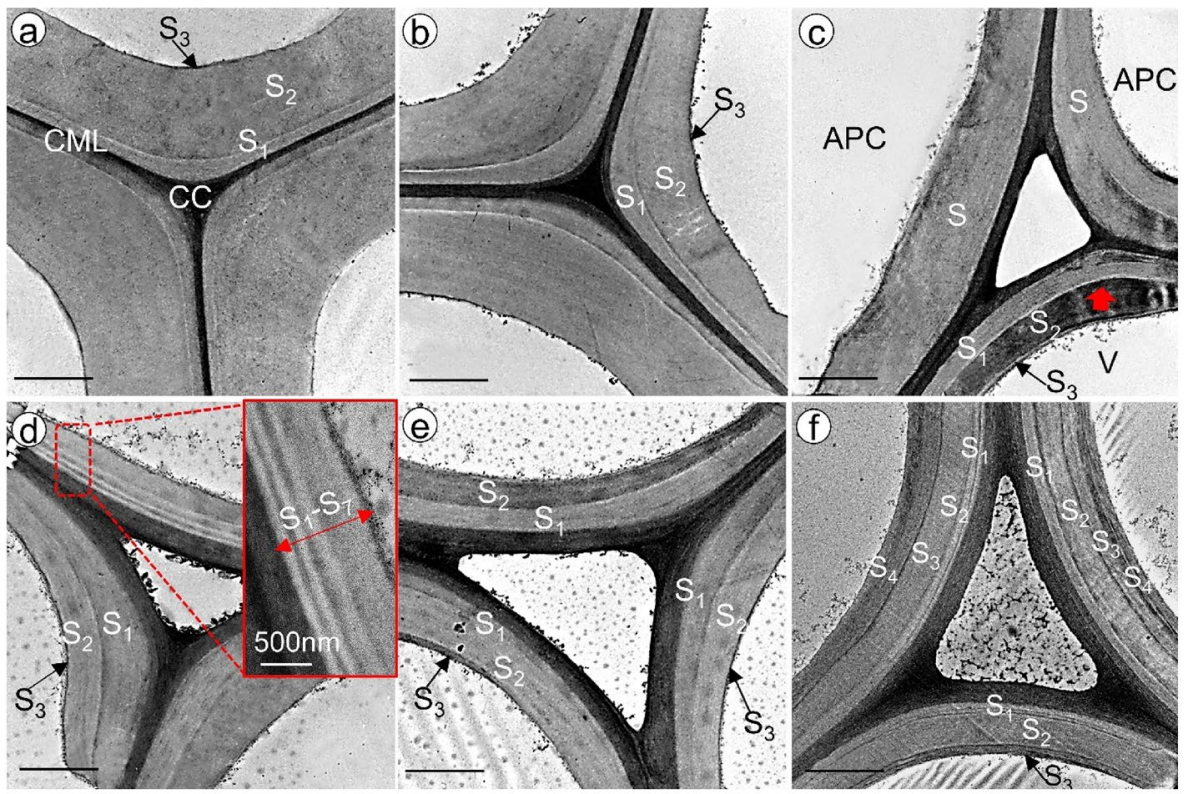

(e)

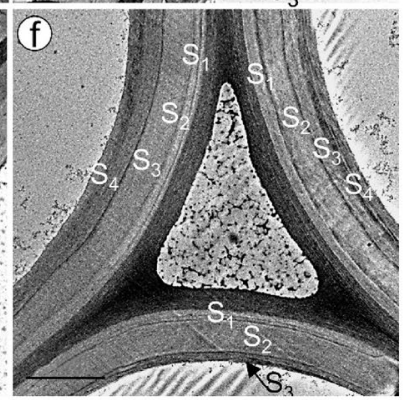

Fig. 2 TEM images of cell wall layering structure of sunflower stalk rind: a PF; b XF; $\mathbf{c}$ APC and V; $\mathbf{d}$ XRPC; e PRPC; and $\mathbf{f}$ GPC. Scale bars indicate $2 \mu \mathrm{m}$ 


\section{Cell wall layering structure}

\section{Morphological characteristics of the cell wall}

The TEM images showed the cell wall layering structure of sunflower stalk rind (Fig. 2). The cell walls of fibers, V, and parenchyma cells were divided into the ML, P, and $\mathrm{S}$. The boundary between the ML and P was not clearly distinguishable because of its high density and extreme thinness. Therefore, both the ML and the contiguous $\mathrm{P}$ were referred to as the CML [20]. The $\mathrm{S}$ of the PF was divided into an outer $\left(S_{1}\right)$, a middle $\left(S_{2}\right)$, and an inner layer $\left(S_{3}\right)$ (Fig. 2a). The $S$ layering structure of the XF resembled that of the $P F$, and was also divided into $S_{1}, S_{2}$, and $S_{3}$ (Fig. 2b). The layering structure of the $S$ of stalk rind fibers was similar to that of wood fibers [21], except that the $\mathrm{S}_{3}$ of stalk rind fibers was very thin, which was occasionally difficult to distinguish from the $S_{2}$. The $S$ of the $V$ was also differentiated into $S_{1}, S_{2}$, and $S_{3}$, in which the $S_{1}$ was clearly distinguished from the $S_{2}$, and the $S_{3}$ was very thin (Fig. 2c).

The layering structure of the $S$ of parenchyma cells in stalk rind varied with the types of parenchyma cells. The $\mathrm{S}$ of the APC had a non-layered cell wall organization, and these cells were mostly distributed close to the vessels (Fig. 2c). The APC in oak earlywood also showed the characteristics of non-layered cell wall organization [22]. The $\mathrm{S}$ of the XRPC was resolved into three $\left(\mathrm{S}_{1}-\mathrm{S}_{3}\right)$ or seven layers $\left(S_{1}-S_{7}\right)$ (light and dark alternation) (Fig. $2 d$ ). XRPCs with the $S$ divided seven layers were usually distributed between XFs. The $\mathrm{S}$ of the PRPC was differentiated into two $\left(S_{1}, S_{2}\right)$ or three layers $\left(S_{1}-S_{3}\right)$, and PRPCs with the $S$ divided two layers was generally distributed in the $\mathrm{X}$ (Fig. 2e). The $\mathrm{S}$ of ray parenchyma cells in Cornus alba similarly consisted of two well-defined layers [23]. The $S$ of the GPC was divided into three $\left(S_{1}-S_{3}\right)$ or four layers $\left(\mathrm{S}_{1}-\mathrm{S}_{4}\right)$ (Fig. $2 \mathrm{f}$ ). GPCs with the $\mathrm{S}$ divided four layers was distributed near the Ep. To summarize, the $S$ of parenchyma cells of sunflower stalk rind showed a nonlayered cell wall organization or could be divided into two, three, four and seven layers, with three layers being the most common. It was interesting to find that the CCs among parenchyma cells in stalk rind were all intercellular space, and the volume of intercellular space in the GPC and PRPC was usually larger than that of the APC and XRPC. The intercellular space was most characteristic of mature tissue. The parenchyma cells in sunflower stalk rind were mature and fully differentiated, which was the outstanding characteristic of annual grass plants different from wood.

When the TEM was used to analyze the lignin distribution in cell wall, the ultra-thin sections needed to be stained by $\mathrm{KMnO}_{4} . \mathrm{KMnO}_{4}$ having a special reactivity with lignin, reacted fast with the double bonds in lignin molecules by forming manganese dioxide, which deposited on the reaction sites [24]. According to the difference in the intensity of staining at the reaction site, the high and low lignin concentrations were determined [25]. As shown in Fig. 2, the staining intensity was highest in the CC of fibers, followed by the CML of each cell, and the $S$ layer with a lower staining intensity. That was, the $\mathrm{CC}$ of fiber cells had the highest lignin concentration, followed by the CML of each cell, and the S layer had a lower lignin concentration. Overall, the staining intensity of $\mathrm{S}_{2}$ layer of vessel was higher than that of fiber and parenchyma cells, and the $S_{2}$ layer was the main part of cell wall. Hence, the lignification degree of vessel in stalk rind was higher than that of fiber and parenchyma cells (Fig. 2c arrow). Plant vessels mainly transported water and inorganic salts, which were subjected to great pressure of transpiration. The high degree of lignification of the vessel cell wall can increase the pressure resistance, so as to protect it from collapse during transporting [26].

\section{Quantification of cell wall layers}

On comparing the thickness of cell wall layers of fibers, $\mathrm{V}$ and parenchyma cells in the stalk rind, only parenchyma cells with the $\mathrm{S}$ divided three layers were selected for measurement. Figure 3 shows the average thickness of each layer in stalk rind cell walls. The order of average cell wall thickness was $\mathrm{PF}>\mathrm{XF}>\mathrm{V}>\mathrm{GPC}>\mathrm{APC}>\mathrm{XRPC}>\mathrm{PR}$ $P C$. The thickness of $S_{2}$ layer of fibers, vessels and parenchyma cells in stalk rind was the largest, with an average thickness of $0.55-2.43 \mu \mathrm{m}$, followed by $S_{1}$ layer, with an average thickness of $0.20-0.57 \mu \mathrm{m}$. The thickness of CML layer and $S_{3}$ layer was the smallest, with an average

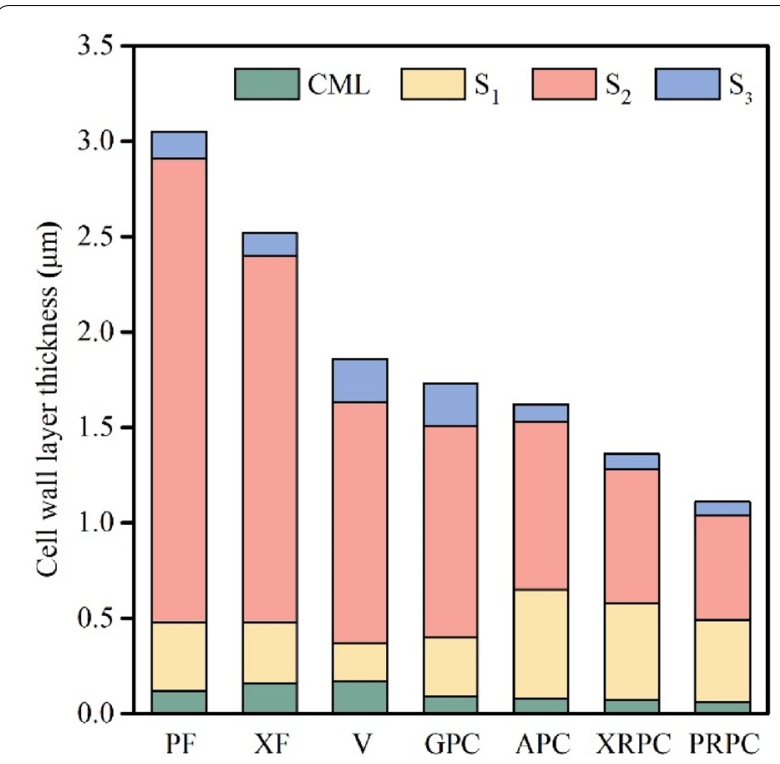

Fig. 3 The thickness of each layer in sunflower stalk rind cell walls 
thickness of $0.06-0.17 \mu \mathrm{m}$ and $0.07-0.23 \mu \mathrm{m}$, respectively. The average thickness of $\mathrm{S}_{2}$ layer of the PF was greater than that of the $\mathrm{XF}$, which indicated that the XF had a lower cell wall thickness compared to the PF. The average thickness of the $\mathrm{S}_{2}$ layer of the GPC was higher than that of APC, XRPC, and PRPC, which was the same as the features of cell wall thickness of basic parenchyma cells and vascular parenchyma cells in bamboo [27].

\section{Pit characteristics of cells}

\section{Type and distribution of pits}

The pit is a hole or concave in the process of plant secondary wall thickening [5]. The pit is the most obvious structural feature on the cell wall, and is the main transverse channel for water or nutrient transport in plants [28]. The SEM images showed pits characteristics of sunflower stalk rind cells (Fig. 4). The pits of the PF were mostly bordered (Fig. 4a), while pits of the XF were simple (Fig. 4b). The pits of both PF and XF were randomly distributed on the cell wall, but the number of pits in the XF was more than that in the PF. Pits of the V were bordered, and were distributed in an alternate pattern (Fig. 4c). Pits of the XRPC, APC, and GPC were simple, and were scattered randomly throughout the cell wall. The distribution of pits in the XRPC and APC was sparse and the pit aperture was large, while that in the GPC was dense and the pit aperture was small (Fig. $4 \mathrm{~d}-\mathrm{f}$ ). Combined with the analysis of the anatomy and cell wall layering structure, the stalk rind had the characteristics of many parenchyma cells, thin cell wall of parenchyma cells, the intercellular space in CC among parenchyma cells, and a large number of pits on cell wall, which were conducive to the penetration of liquid chemicals during the conversion and utilization [29].

\section{Morphological characteristics of pit membranes}

The PM was a very important structural part of the pits, which was a safety valve for water transport in plants [8]. Figure $5 \mathrm{a}-\mathrm{d}$ shows the PMs between the cells (interVs, V-XF, XF-APC, and XF-XRPC) in sunflower stalk rind, and Fig. 5e-g shows the PMs between parenchyma cells (inter-GPCs, inter-XRPCs, and inter-PRPCs). It was worth noting that the PMs between parenchyma cells was perforated by plasmodesmata (Fig. $5 \mathrm{e}-\mathrm{g}$ inset), while the PMs between other cells was not perforated. It might be because on the one hand, plasmodesmata are generally not found in bordered pit membranes that were formed between treachery cells (i.e., tracheid and vessel). In angiosperms, plasmodesmata are absent or rare in bordered pit membranes of inter-tracheid and intervessel bordered pits. On the other hand, plasmodesmata are abundant in a simple pit of parenchyma cells [30]. All PMs had perforations. Perforations allowed for free passage of water and nutrients, while limiting the passage of pathogens between cells [31]. Furthermore, the morphology of plasmodesmata on the PMs between parenchyma

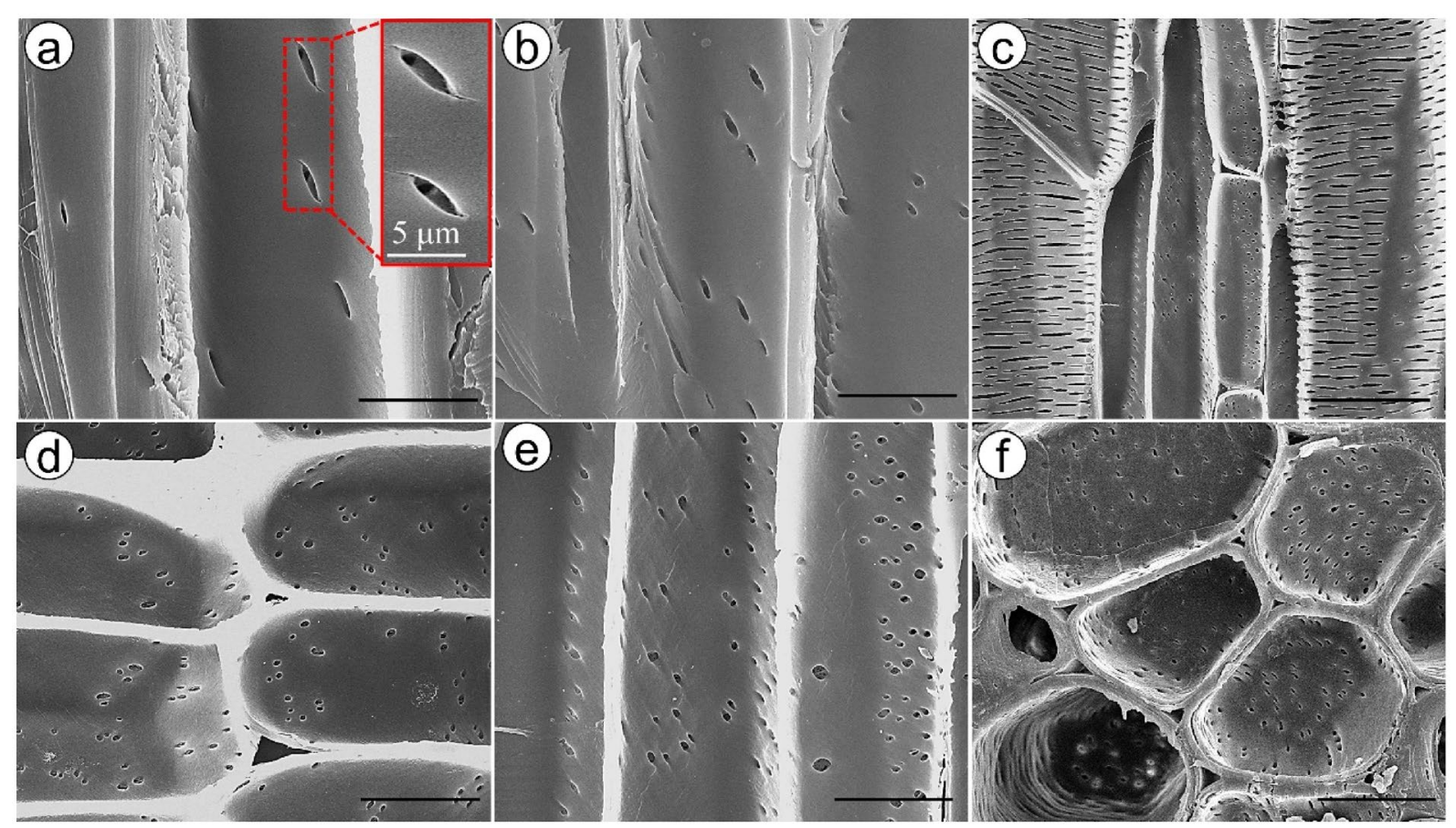

Fig. 4 SEM images of the pits of sunflower stalk rind cells: a PF; $\mathbf{b} X F ; \mathbf{c} V ; \mathbf{d} X R P C ; \mathbf{e} A P C ;$ and $\mathbf{f}$ GPC. Scale bars indicate $10 \mu \mathrm{m}$ 

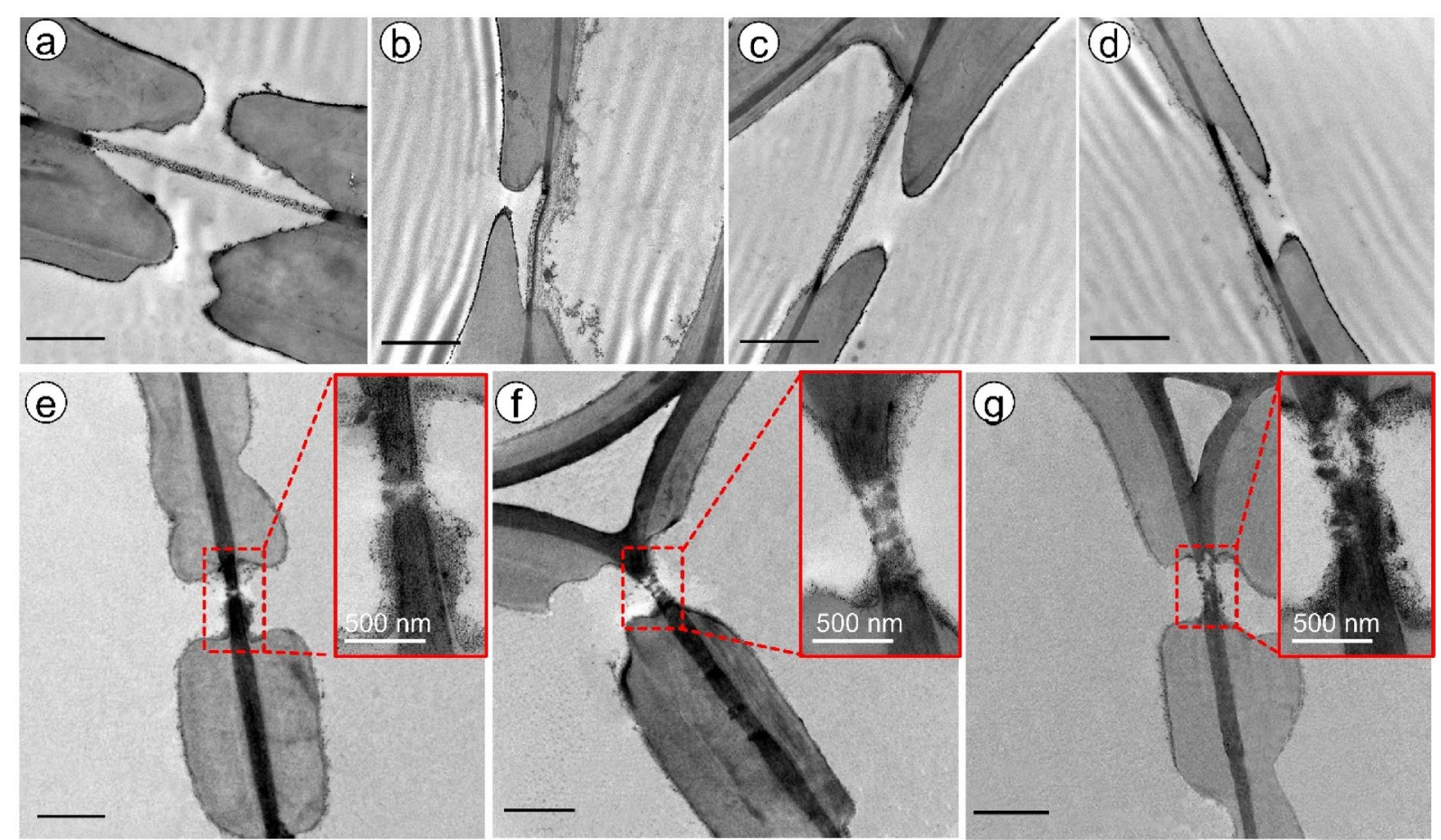

Fig. 5 TEM images of pit membranes between sunflower stalk rind cells: a $\vee-V ; \mathbf{b} \vee-X F ; \mathbf{c} A P C-V ; \mathbf{d} X R P C-V ; \mathbf{e} G P C-G P C ; \mathbf{f} X R P C-X R P C ;$ and $\mathbf{g} P R P C-$ PRPC. Scale bars indicate $2 \mu \mathrm{m}$

cells in stalk rind was different, which might be related to the physiological function of parenchyma cells. The GPCs are located near the Ep, and their main function is to store starch granules. The XRPCs are close to the V and involve in the transport capacity of the $\mathrm{V}$, transporting water, nutrition, etc. However, the PRPC connects outward to the cortex and inward to the pith, and has both functions of the GPC and XRPC [32].

\section{Quantification of pit membranes}

Figure 6 shows the measurement results of $T_{\mathrm{PM}}$ and $D_{\mathrm{PM}}$ of sunflower stalk rind cells. The order of the $T_{\mathrm{PM}} \quad$ was $\mathrm{V}-\mathrm{V}>\mathrm{V}-\mathrm{XF}>\mathrm{V}-\mathrm{APC}>\mathrm{V}-\mathrm{XRPC}>\mathrm{GPC}-$ GPC $>$ PRPC-PRPC $>$ XRPC-XRPC. The order of the $D_{\mathrm{PM}}$ was $\mathrm{V}-\mathrm{XRPC}>\mathrm{V}-\mathrm{APC}>\mathrm{V}-\mathrm{XF}>\mathrm{V}-\mathrm{V}>\mathrm{XRPC}-$ XRPC $>$ PRPC-PRPC $>$ GPC-GPC. The $T_{\mathrm{PM}} \quad(0.33-$ $0.43 \mu \mathrm{m})$ and the $D_{\mathrm{PM}}(3.17-5.15 \mu \mathrm{m})$ between the cells (inter-Vs, V-XF, V-APC, and V-XRPC) were all larger than the $T_{\mathrm{PM}}(0.14-0.23 \mu \mathrm{m})$ and the $D_{\mathrm{PM}}(1.32-1.63 \mu \mathrm{m})$ between parenchyma cells (inter-GPCs, inter-XRPs, and inter-PRPCs). The $D_{\mathrm{PM}}$ was related to the aperture of simple pit [33], and the $D_{\mathrm{PM}}$ results of parenchyma cells were also consistent with the larger pit aperture in XRPC than that in GPC.

\section{Lignin distribution in cell walls}

Autofluorescence images can visually display lignin distribution in the cell walls [34]. Figure 7 shows the autofluorescence images of sunflower stalk rind cell walls. The CC of the PF and XF assumed the greatest autofluorescence, while the CML of fibers, $\mathrm{V}$, and parenchyma cells displayed greater autofluorescence than that of the $\mathrm{S}$ layer. The autofluorescence intensity of the $\mathrm{V}$ cell walls was higher than that of parenchyma and fiber cell walls. It suggested that the lignin concentration in the $\mathrm{CC}$ and CML was higher than that in the $\mathrm{S}$ layer, and the vessels are more lignified than parenchyma cells and fibers. The distribution of lignin in stalk rind cell walls was similar to that of poplar and wheat straw [35].

The distribution of lignin was indirectly analyzed by $\mathrm{Mn}-\mathrm{K} \alpha \mathrm{X}$-ray point scanning method [36]. Figure 8 shows the $\mathrm{Mn}-\mathrm{K} \alpha \mathrm{X}$-ray count measurements of the regions in the stalk rind cell walls. The $\mathrm{CC}$ of the fibers had the highest Mn-K $\alpha$ X-ray counts. The Mn-K $\alpha$ X-ray counts of the CML in fibers, $\mathrm{V}$, and parenchyma cells were higher than that of the $\mathrm{S}$ layer. The order of the $\mathrm{Mn}-$ $\mathrm{K} \alpha \mathrm{X}$-ray counts of the $\mathrm{S}$ layer was $\mathrm{V}>\mathrm{APC}>\mathrm{XRPC}>\mathrm{PRP}$ $\mathrm{C}>\mathrm{PF}>\mathrm{XF}>\mathrm{GPC}$. The SEM-EDXA measurements were consistent with the FM and TEM observations. 


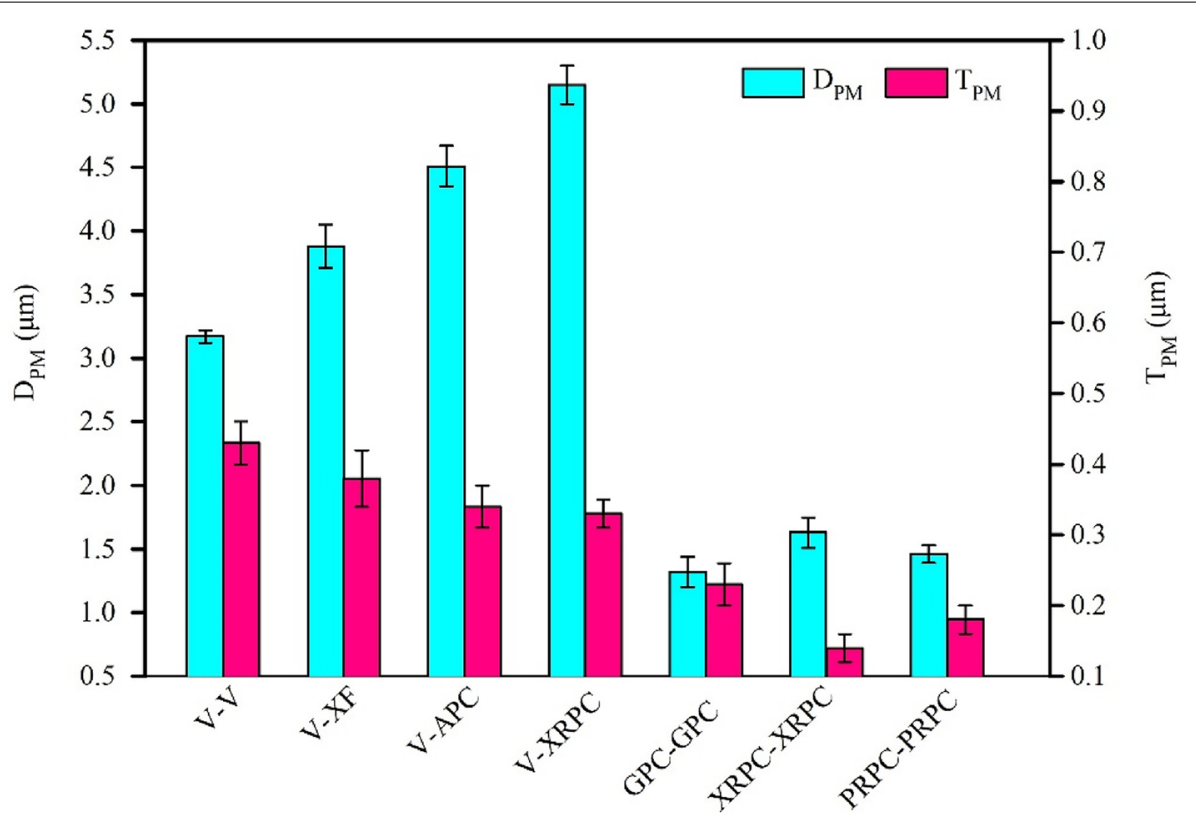

Fig. 6 Thickness $\left(T_{P M}\right)$ and diameter $\left(D_{P M}\right)$ of pit membranes between sunflower stalk rind cells
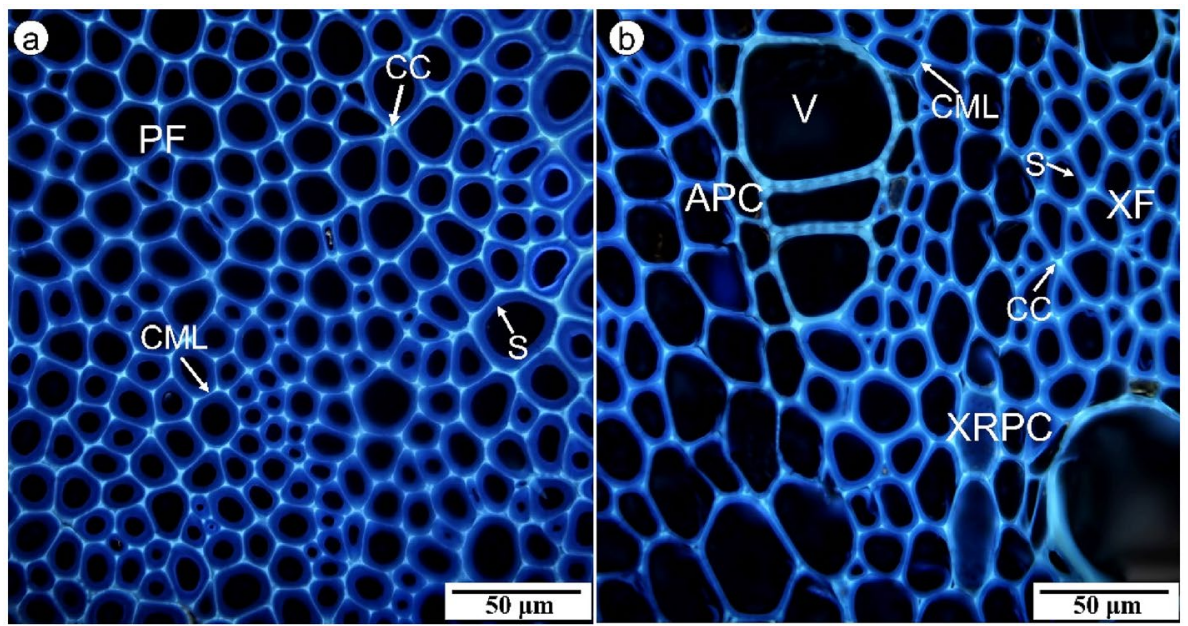

Fig. 7 Autofluorescence images of sunflower stalk rind cell walls: a Ph; $\mathbf{b}$ X

\section{Conclusions}

(1) Sunflower stalk rind consisted of PF, XF, V, GPC, APC, XRPC and PRPC.

(2) The layering structure of the second wall (S) and the thickness of each layer were different between cell types. The $\mathrm{S}$ of $\mathrm{PF}, \mathrm{XF}$, and $\mathrm{V}$ were divided into three layers $\left(\mathrm{S}_{1}-\mathrm{S}_{3}\right)$. The $\mathrm{S}$ of APC, GPC, XRPC, and PRPC showed a non-layered cell wall organization or differentiated two $\left(\mathrm{S}_{1}, \mathrm{~S}_{2}\right)$ to seven layers $\left(\mathrm{S}_{1}-\mathrm{S}_{7}\right)$, with three layers being the most common.
The order of average thickness of each cell wall was $\mathrm{PF}>\mathrm{XF}>\mathrm{V}>\mathrm{GPC}>\mathrm{APC}>\mathrm{XRPC}>\mathrm{PRPC}$. The CCs among parenchyma cells were intercellular space.

(3) The type, distribution of pits and the ultrastructure of PMs were diverse. The pits of $\mathrm{V}$ and PF were mostly bordered, while pits of XRPC, APC, GPC, and XF were simple. The pits on parenchyma and fiber cell walls were scattered randomly, and the pits on the $\mathrm{V}$ cell walls were distributed in an alternate pattern. The PMs between parenchyma cells were perforated by plasmodesmata, and the morphology 


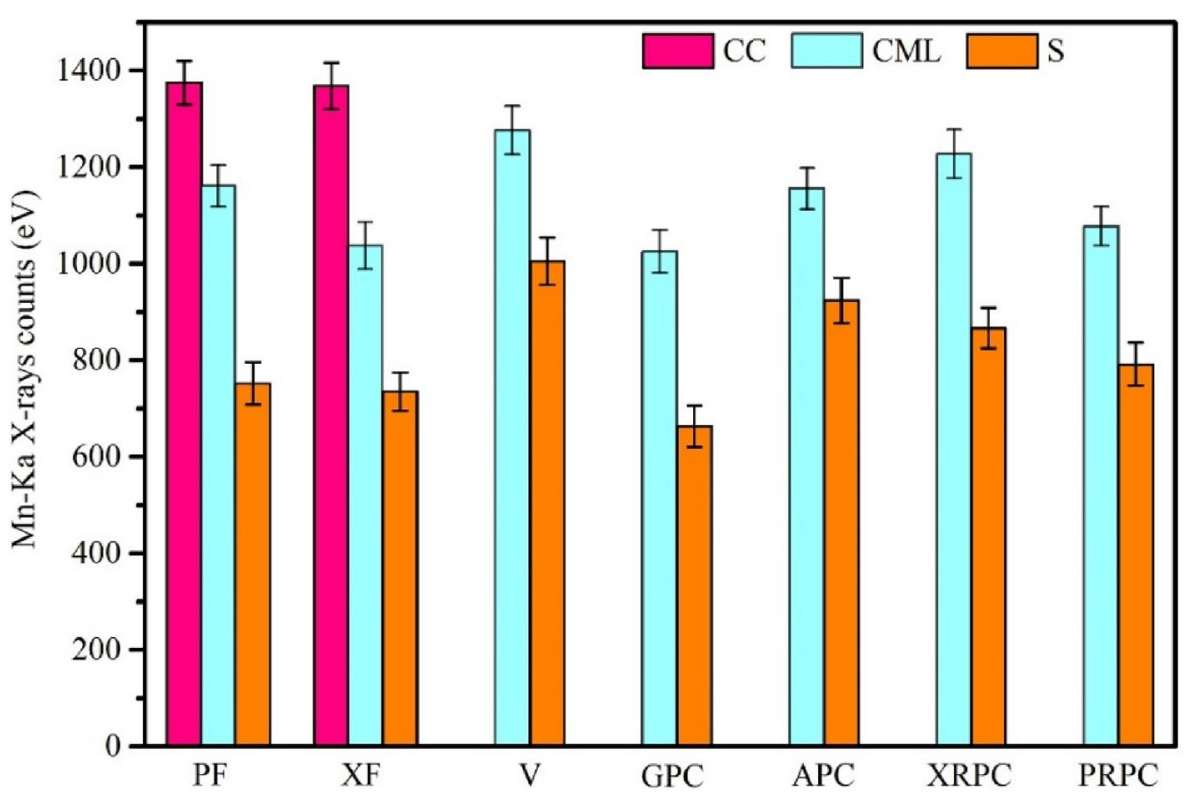

Fig. 8 The Mn-Ka X-rays counts of the regions in sunflower stalk rind cell walls by SEM-EDXA

of plasmodesmata varied with the types of parenchyma cells. The thickness and diameter of the PMs between the cells (inter-Vs, V-XF, V-APC, and $\mathrm{V}$-XRPC) were $0.33-0.43 \mu \mathrm{m}$ and $3.17-5.15 \mu \mathrm{m}$, respectively. The thickness and diameter of the PMs between parenchyma cells were $0.14-0.23 \mu \mathrm{m}$ and $1.32-1.63 \mu \mathrm{m}$, respectively.

(4) The lignin concentration is the highest in the CCs of fibers, followed by the CML, and the lowest is in the $\mathrm{S}$ layer. The $\mathrm{V}$ are more lignified than parenchyma cells and fibers.

\begin{abstract}
Abbreviations
Ep: Epidermis; GPC: Ground parenchyma cells; Ph: Phloem; VC:Vascular cambium; X: Xylem; PRPC: Pith ray parenchyma cells; V: Vessels; APC: Axial parenchyma cells; XRPC: Xylem ray parenchyma cells; XF: Xylem fibers; PF: Phloem fibers; ML: Middle lamella; P: Primary wall; S: Secondary wall; CML: Compound middle lamella; CC: Cell corner; PM: Pit membrane; $T_{\text {PM: }}$ Pit membrane thickness; $D_{\text {PM: }}$ : Pit membrane dimeter; LM: Light microscopy; SEM: Scanning electron microscopy; FM: Fluorescence microscopy; TEM: Transmission electron microscopy; SEM-EDXA: Scanning electron microscope with energy dispersive $\mathrm{X}$-ray analysis; SD: Standard deviation.
\end{abstract}

\section{Acknowledgements}

The authors are grateful for the support of the National Natural Science Foundation of China (Grants No. 31070524 and 31600474) and the Priority Academic Program Development (PAPD) of Jiangsu Higher Education Institutions.

\section{Authors' contributions}

LW conducted the experiments, analyzed the obtained data, and wrote the draft of this manuscript under the supervision of $\mathrm{HZ}$. HR and $\mathrm{SZ}$ contributed to the discussion of the obtained results. All authors read and approved the final manuscript.

\section{Funding}

There is no other funding except the three in the acknowledgements.

Availability of data and materials

All data and materials are available.

\section{Declarations}

\section{Ethics approval and consent to participate}

All authors are working in the same group and consent to participate.

\section{Consent for publication}

All authors consent to publish the work.

\section{Competing interests}

The authors declare no conflicts of interest.

\section{Author details}

${ }^{1}$ Jiangsu Co-Innovation Center for Efficient Processing and Utilization of Forest Resources, Jiangsu Provincial Key Lab of Pulp and Paper Science and Technology, Nanjing Forestry University, Nanjing 210037, China. ${ }^{2}$ College of Textile Light Industry, Inner Mongolia University of Technology, Hohhot 010080, China.

Received: 15 July 2021 Accepted: 23 November 2021

Published online: 07 December 2021

\section{References}

1. Chundawat S, Donohoe BS, Sousa L, Elder T, Agarwal UP, Lu F, Ralph J, Himmel ME, Balan V, Dale BE (2011) Multi-scale visualization and characterization of lignocellulosic plant cell wall deconstruction during thermochemical pretreatment. Energy Environ Sci 4:973-984 
2. Keegstra K (2010) Plant cell walls. Plant Physiol 154:483-486

3. Cosgrove DJ, Jarvis MC (2012) Comparative structure and biomechanics of plant primary and secondary cell walls. Front Plant Sci 3:204-210

4. Himmel ME, Ding SY, Johnson DK, Adney WS, Nimlos MR, Brady JW, Foust TD (2007) Biomass recalcitrance: engineering plants and enzymes for biofuels production. Sci 315:804-807

5. Cosgrove DJ (2005) Growth of the plant cell wall. Nat Rev Mol Cell Biol 6:850-861

6. Yang F, Mitra P, Zhang L, Prak L, Verhertbruggen Y, Kim JS, Sun L, Zheng K, Tang K, Auer M (2013) Engineering secondary cell wall deposition in plants. Plant Biotechnol J 11:325-335

7. Donaldson LA, Baas P (2019) Wood cell wall ultrastructure - the key to understanding wood properties and behaviour. IAWA J 40:645-672

8. Choat B, Cobb AR, Jansen S (2010) Structure and function of bordered pits: new discoveries and impacts on whole-plant hydraulic function. New Phytol 177:608-626

9. Jansen S, Choat B, Pletsers A (2009) Morphological variation of intervessel pit membranes and implications to xylem function in angiosperms. Am J Bot 96:409-419

10. Mehdikhani H, Torshizi HJ, Ghalehno MD (2019) Deeper insight into the morphological features of sunflower stalk as biorefining criteria for sustainable production. Nord Pulp Pap Res J 34:250-263

11. Marechal V, Rigal $L$ (1999) Characterization of by-products of sunflower culture - commercial applications for stalks and heads. Ind Crops Prod 10:185-200

12. Rudi H, Resalati H, Eshkiki RB, Kermanian H (2016) Sunflower stalk neutral sulfite semi-chemical pulp: an alternative fiber source for production of fluting paper. J Cleaner Prod 127:562-566

13. Mati-Baouche N, De Baynast H, Lebert A, Sun S, Lopez-Mingo CJS, Leclaire P, Michaud P (2014) Mechanical, thermal and acoustical characterizations of an insulating bio-based composite made from sunflower stalks particles and chitosan. Ind Crops Prod 58:244-250

14. Martínez ML, Sánchez S, Bravo V (2012) Production of xylitol and ethanol by Hansenula polymorpha from hydrolysates of sunflower stalks with phosphoric acid. Ind Crops Prod 40:160-166

15. Zhurka M, Spyridonidis A, Vasiliadou IA, Stamatelatou K (2020) Biogas production from sunflower head and stalk residues: effect of alkaline pretreatment. Mol 25:164-179

16. Sun S, Mathias JD, Toussaint E, Grédiac M (2013) Hygromechanical characterization of sunflower stems. Ind Crops Prod 46:50-59

17. Čufar K, Gričar J, Zupančič M, Koch G, Schmitt U (2008) Anatomy, cell wall structure and topochemistry of water-logged archaeological wood aged 5,200 and 4,500 years. IAWA J 29:55-68

18. Spurr AR (1969) A low-viscosity epoxy resin embedding medium for electron microscopy. J Ultrastruct Res 26:31-43

19. Georg VA, Alan C, Prendin AL, Čufar K, Carrer M (2016) Quantitative wood anatomy_practical guidelines. Front Plant Sci 7:781-796

20. Adobes-Vidal M, Frey M, Keplinger T (2020) Atomic force microscopy imaging of delignified secondary cell walls in liquid conditions facilitates interpretation of wood ultrastructure. J Struct Biol 211:107532
21. Fengel D, Wegener G (1984) Wood: chemistry, ultrastructure, reactions. Walter de Gruyter Press, Berlin, p 87

22. Kim JS, Daniel G (2016) Variations in cell wall ultrastructure and chemistry in cell types of earlywood and latewood in English oak (Quercus robur). IAWA J 37:383-401

23. Ma J, Ji Z, Zhou X, Zhang Z, Xu F (2013) Transmission electron microscopy, fluorescence microscopy, and confocal Raman microscopic analysis of ultrastructural and compositional heterogeneity of Cornus alba $\mathrm{L}$. wood cell wall. Microsc Microanal 19:243-253

24. Singh A, Daniel G, Nilsson $T$ (2002) Ultrastructure of the $S_{2}$ layer in relation to lignin distribution in Pinus radiata tracheids. J Wood Sci 48:95-98

25. Bland DE, Foster RC, Logan AF (1971) The mechanism of permanganate and osmium tetroxide fixation and the distribution of lignin in the cell wall of Pinus radiata. Holzforschung 25:137-143

26. Abdul Khalil HPS, Yusra AFI, Bhat AH, Jawaid M (2010) Cell wall ultrastructure, anatomy, lignin distribution, and chemical composition of Malaysian cultivated kenaf fiber. Ind Crops Prod 31:113-121

27. Lian C, Liu R, Zhang S, Yuan J, Luo J, Yang F, Fei B (2020) Ultrastructure of parenchyma cell wall in bamboo (Phyllostachys edulis) culms. Cellulose 27:7321-7329

28. Choat B, Pittermann J (2010) New insights into bordered pit structure and cavitation resistance in angiosperms and conifers. New Phytol 182:557-560

29. Lian C, Zhang S, Liu X, Luo J, Yang F, Liu R, Fei B (2019) Uncovering the ultrastructure of ramiform pits in the parenchyma cells of bamboo [Phyllostachys edulis (Carr.) J. Houz.]. Holzforschung 74:1-11

30. Barnett JR (1982) Plasmodesmata and pit development in secondary xylem elements. Planta 155:251-260

31. Pittermann J, Choat B, Jansen S, Stuart SA, Lynn L, Dawson TE (2010) The relationships between xylem safety and hydraulic efficiency in the Cupressaceae: the evolution of pit membrane form and function. Plant Physiol 153:1919-1931

32. Eames AJ, Macdaniels LH (1951) An introduction to plant anatomy. McGraw Hill Book Company, New York, p 121

33. Lian C, Liu R, Cheng X, Zhang S, Luo J, Yang S, Liu X, Fei B (2019) Characterization of the pits in parenchyma cells of the moso bamboo [Phyllostachys edulis (Carr.) J. Houz.] culm. Holzforschung 73:629-636

34. Donaldson L, Vaidya A (2017) Visualising recalcitrance by colocalisation of cellulase, lignin and cellulose in pretreated pine biomass using fluorescence microscopy. Sci Rep 7:44386

35. Donaldson L, Hague J, Snell R (2001) Lignin distribution in coppice poplar, linseed and wheat straw. Holzforschung 55:379-385

36. Xu F, Zhong XC, Sun RC, Lu Q (2006) Anatomy, ultrastructure and lignin distribution in cell wall of Caragana korshinskii. Ind Crops Prod 24:186-193

\section{Publisher's Note}

Springer Nature remains neutral with regard to jurisdictional claims in published maps and institutional affiliations.

\section{Submit your manuscript to a SpringerOpen ${ }^{\circ}$ journal and benefit from:}

- Convenient online submission

- Rigorous peer review

- Open access: articles freely available online

- High visibility within the field

Retaining the copyright to your article

Submit your next manuscript at springeropen.com 